gene effects. Genetical illustrations are also common among the useful exercises which follow each of the first eight chapters. A list of references can be found at the end of every chapter as well as a short list of books on matrix algebra.

As a whole the book is well balanced, although a more detailed account of the variance-covariance matrix would have been justified. And one last point: to geneticists, drosophila (pp. $3,3^{8}, 4^{\circ}$ ) is still Drosophila.

G. Simahen.

\title{
GENETICS AS HISTORY
}

THE FOUNdAtions Of Genetics. F. A. E. Crew. Pergamon Press, 1966. Pp. 202. $21 \mathrm{~s}$.

A SHORT HISTORY OF GENETICS. THE DEVELOPMENT OF SOME MAIN LINES OF THOUGHT: 1864-1939. L. C. Dunn. McGraw-Hill Book Co., 1965. Pp. 261. 28 s.

In scope and subject matter these two books have much in common, but in other respects they differ widely. Professor Crew's book is aimed at science sixth-formers, and for such it furnishes in a handy format a textbook on the subject written from the historical angle. Especially valuable are the derivations given for the scientific terms and the well-arranged presentation of "Mendel: the Man", and his "Versuche über Pflanzenhybriden". Professor Dunn's book developed from a course of three lectures which he gave to the Johns Hopkins Hospital in 1964: hence it is aimed at a more informed audience and is not a textbook-style exposition of the subject.

The historical approach is very satisfactory as a means of expounding a subject which has grown up gradually on the basis of careful experimentation and restricted theorising, but where progress has followed obscure pathways and fresh hypotheses have succeeded one another pell-mell this approach tends to confuse the reader. Hence genetics is easy to present from the historical angle up to the beginning of this century. After this, particularly from 1904-09, it becomes difficult, and a full historical treatment would only confuse the uninitiated. Professor Crew has therefore wisely omitted describing Bateson's Reduplication Hypothesis and Morgan's theory of Selective Dominance, and he refers to Bateson's Presence and Absence Theory only in connection with its disproof. The result is an admirably smooth unfolding of the expansion and modification of Mendel's Principles.

Professor Dunn's book is devoted to an exposure of the main lines of thought in genetics, starting with the particulate theories of Spencer and Darwin and concluding at the end of the rg3os when these main lines of thought could be clearly perceived. With this purpose in view the author has dealt only very briefly with the pre-Mendelian hybridists and theorists and the molecular genetics of the r95os and I96os; biographical details of the personalities involved have been kept to a minimum and lengthy quotations avoided wherever possible. The result is an unusually balanced and objective account, free from chauvinistic and partisan influences. To those who are unfamiliar with the German and Dutch literature of the early days of Mendelism Professor Dunn's account of the contributions made by De Vries, Correns and Johannsen will come as a surprise, especially Correns' chromosome theory of 1902 , Dr. Vries' suggestion of 1904 that Röntgen rays be used to produce mutation, and Johannsen's brilliant little book on 
heredity and variation (Om Arvelighed og Variabilitet, 1896). The subtle distinctions between the first speculative expressions of an idea and its subsequent formulation on the basis of experiment and detailed observation are captured in this account. Thus Correns' 1902 mechanism for crossingover, Professor Dunn points out, does not involve the exchange of blocks of units but of one or more pairs at random. This book is provided with a 4-page Glossary and an invaluable I 7-page Bibliography.

R. G. Olby.

\section{FUNGAL MATING-TYPES}

INCOMPATIBILITY IN FUNGI. A Symposium held at the 10th International Congress of Botany at Edinburgh, August 1964. Edited by Karl Esser and John R. Raper. Springer-Verlag, Berlin, 1965. Pp. viii+124, 8vo. Stiff paper bound. DM. 24.

This publication consists of the contributions to a symposium on Incompatibility in Fungi held at the roth International Botanical Congress in Edinburgh in August 1964. The speakers included many of the leading workers in this field. The editors have standardised the terminology of the various contributions, with the exception of Professor J. H. Burnett's paper on the natural history of recombination systems. The papers are introduced by Professor J. R. Raper, and the concluding remarks on the genetical interest of incompatibility in fungi are given by Professor K. Mather. The heterogenic incompatibility of Podospora anserina, in which sexual interaction of different races is prevented by unlike alleles, is discussed by Professor $\mathbf{K}$. Esser, incompatibility in yeasts is described by Professor M. Ahmad, and the function of the mating-type locus in filamentous Ascomycetes by Dr. G. N. Bistis. A further eight papers are concerned largely or entirely with the multiple-allele incompatibility of the Hymenomycetes. Dr. P. J. Snider, in discussing incompatibility and nuclear migration, points out that existing techniques have not yet been fully exploited, and that the mechanisms of the movement of nuclei and its regulation are still quite obscure.

This publication provides a most useful survey of current knowledge and ideas in a subject of outstanding interest to geneticists. It is the more valuable because this symposium coincided with one on Genetic Recombination, which was unfortunate because, not only have most of the investigations of recombination been made with fungi, but the genetical study of incompatibility has led to the finding of novel mechanisms of recombination, notably Dr. A. H. Ellingboe and Professor J. R. Raper's discovery of specific factor transfer. These authors have shown that the mating-type factors in Schizophyllum commune may be specifically transferred from one strain to another, while other genes including a nutritional mutation situated between the two A factor loci are not transferred. Dr. Ellingboe, in his paper on somatic recombination in Basidiomycetes, suggests that episomes may be responsible for these transfers. Another contribution of outstanding interest in the present publication is Dr. S. Dick's repressional inhibition model of the action of the incompatibility factors in Schizophyllum and other Basidiomycetes with multiple-allele incompatibility. According to this hypothesis, the incompatibility loci are regulator genes controlling the production of specific repressor substances. In a monokaryon, the morphogenetic sequence leading to the formation of clamp-connections is repressed, but in a compatible dikaryon it is suggested that allelic differences in the 